\title{
Anemia and Iron Deficiency Related to Inflammation, Helicobacter pylori Infection and Adiposity in Reproductive-age Cuban Women
}

\author{
Gisela M. Pita-Rodríguez MD MS, Beatriz Basabe-Tuero MS PhD, María Elena Díaz-Sánchez MS PhD, \\ Ana María Gómez-Álvarez MD MPH, Derbis Campos-Hernández MS, Caridad Arocha-Oriol, Yoandry Díaz-Fuentes MS, \\ Ileana Puentes-Márquez MS, Dania Herrera-Javier, Elisa Llera-Abreu
}

\begin{abstract}
INTRODUCTION Iron deficiency is the main cause of anemia, but infections, inflammation and other factors also play a role. Anemia in women of childbearing age is a risk for pregnancy, childbirth and childhood development during the first two years of life. In Cuba, per WHO definition, anemia is a moderate public health problem in the third trimester of pregnancy and in preschoolers, with a prevalence of $21.6 \%$, in both cases.
\end{abstract}

OBJECTIVE Estimate prevalence of anemia and iron deficiency in women of childbearing age and assess its relation to inflammation, overweight, central adiposity, H. pylori infection and ingestion of ironrich foods and enhancers of iron absorption.

METHODS A cross-sectional, analytical study was performed in 391 women aged 18-40 years in four municipalities of Havana, Cuba, from February through June 2014. Variables (indicators in parentheses) were anemia (hemoglobin), iron deficiency (ferritin), nutritional status (body mass index and waist circumference), inflammation (C-reactive protein, acid alpha 1-glycoprotein and interleukin 6), H. pylori infection and ingestion of iron-rich foods. SPSS 20.0 and Epi Info 7.1.2.0 were used for statistical analysis.

RESULTS Anemia prevalence was $24.6 \%$ (96/391); iron deficiency, $68 \%$ (266/391); H. pylori infection, $47.1 \%$ (184/391); inflammation

\section{INTRODUCTION}

Anemia is a global health problem that affects all countries, with higher prevalence in low- and middle-income countries (LMIC). In 2011, children aged 6-59 months had the highest prevalence of anemia with an estimated $42.6 \%$ worldwide. The lowest prevalence was recorded in nonpregnant women, $29 \%$, and within this population, it was lowest in the region of the Americas, $16.5 \%$. Estimated prevalence of anemia in women of reproductive age was $23.9 \%-34.8 \%$.[1] WHO defines anemia prevalence of $20 \%-39.9 \%$ as a moderate public health problem.[2]

Anemia has several causes, often coexisting, the main one identified as inadequate (quantitatively and qualitatively) intake of iron-rich foods. It is assumed that half of anemia is caused by iron deficiency; however, there are additional nutritional causes, including deficiency of other micronutrients such as folate, cobalamin, riboflavin or vitamin A.[2,3] Parasitism, malaria, tuberculosis and HIV are infectious causes of anemia. Cancer is one of the chronic conditions with concomitant anemia. Inherited or acquired errors of hemoglobin $(\mathrm{Hb})$ synthesis, such as sickle cell disease, thalassemias, presence of $\mathrm{HbE}$ or disorders in the production or survival of erythrocytes, may also be causes of anemia in specific populations.[2,3] detected by C-reactive protein, $8.4 \%$ (33/391) and by alpha-1-glycoprotein, $19.9 \%$ (78/391). Limited results are included for interleukin 6 , which was determined in fewer cases (96). Excess body weight was found in $38.7 \%(150 / 388)$ and increased central adiposity in $26.7 \%(101 / 378)$. Iron deficiency was the main cause of anemia (OR 2.68). Central adiposity, excess body weight, and iron deficiency were positively associated with inflammation (OR of 1.77, 1.23 and 1.72, respectively), whereas $H$. pylori infection was negatively associated with iron deficiency and anemia (OR 0.75 and 0.94 , respectively). Low consumption of meat (OR 1.17) and vegetables (OR 1.36) showed discrete limited positive associations with iron deficiency, as well as low consumption of eggs (OR 1.69) and vegetables (OR 1.56) with anemia.

CONCLUSIONS Anemia is a moderate public health problem in the studied group, but with iron deficiency present in two thirds of the population and associated with anemia. Risk factors for anemia and iron deficiency, such as menorrhagia and bacterial or viral infections, should be assessed in women of childbearing age, to support interventions needed to reduce risks in pregnancy and childbirth.

KEYWORDS Anemia, iron deficiency, women, women of childbearing age, inflammation, Helicobacter pylori, obesity, adiposity, Cuba
Inflammation is a cause of anemia commonly seen in medical practice, but the size of its contribution is unknown in LMIC countries. [4] Inflammation is a reaction of an organism to bacterial or viral infections,[5] and an expression of chronic disease development, as well as obesity.[6] During the inflammatory process, interleukins are secreted that in turn stimulate liver secretion of the hormonal peptide, hepcidin. Hepcidin acts on intestinal cells, preventing iron absorption from food, and on the mononuclear phagocytic system, sequestering circulating iron.[7,8] In such cases, iron deficiency is due to both low dietary absorption and low bodily utilization.

Obesity is characterized by chronic, systemic, low-grade inflammation, with increased C-reactive protein (CRP), alpha 1-acid glycoprotein (AGP) and interleukin 6 (IL-6).[9-12] Therefore, overweight and obesity are related to iron deficiency and anemia through hepcidin secretion stimulated by high levels of IL-6 during inflammation.[10] In LMIC, there is a higher dual burden of malnutrition and infections, so assessment of the potential influence of these factors on serum ferritin (protein indicating iron nutritional status) is important in order to explain the prevalence of iron deficiency and its relation to anemia.[6]

Some authors associate iron deficiency anemia with $H$. pylori infection, because of the chronic gastritis it produces and 
consequent malabsorption of iron from food.[13,14] In LMIC, such as Cuba, colonization by $H$. pylori occurs during childhood and, if left untreated, remains a chronic infection into adulthood. A multicountry study of Latin American school children found an $\mathrm{H}$. pylori prevalence of $47.7 \%$, but not associated with anemia.[15] However, it is difficult to accurately estimate $H$. pylori infection's contribution to development of anemia in women, since precision depends on the extent of infection, symptom severity and nutritional status.[13,14]

Proportions of anemia's different causes vary among population groups and geographies.[1] Women of reproductive age are a risk group for anemia. This group exhibits factors that contribute to iron deficiency anemia, such as menstrual blood loss and scarce intake of iron-rich foods.[16] In turn, anemia in these women is a risk for pregnancy, childbirth and child development during the first year of life,[17] so deserves greater surveillance for improved maternal and child health.[3] WHO proposed the goal of reducing anemia by $50 \%$ by 2025 in women of reproductive age, compared to the baseline established in 1993-2005.[18]

By WHO definitions,[2] anemia in Cuba is considered a moderate public health problem, with a $21.6 \%$ prevalence in the third trimester of pregnancy.[17,19] The same prevalence was found between 2010 and 2013, in 4162 children aged 6-59 months.[20] A 2008 study of 1802 women aged 15-49 years in the eastern provinces of Cuba found anemia prevalence of $19.9 \%$.[21] In 2015, there were $2,748,362$ women in that age group in Cuba.[22]

We are unaware of any studies conducted in Cuba to assess risk factors associated with anemia in women of childbearing age. The objective of this study was to estimate the prevalence of anemia and iron deficiency in this age group and assess their relation to inflammation, overweight, central adiposity, $H$. pylori infection, and intake of iron-rich foods and enhancers of iron absorption.

\section{METHODS}

Study type and population An analytical, cross-sectional study was carried out from February through June 2014. Apparently healthy women, aged 18-40 years, living in 4 Havana municipalities (Playa, Cerro, Centro Habana and 10 de Octubre) were selected by two-stage cluster sampling.

Sample size was calculated using OpenEpi V3, according to the estimated population of women aged 20-39 years in Havana in 2011 (342,806), based on data from the National Bureau of Statistics and Information (ONEI),[23] and an estimated prevalence of $H$. pylori infection of $50 \%$ found in other studies in different population groups.[20] Maximum permissible type I error of $5 \%, 95 \%$ power and a design effect of 1 were accepted to obtain the minimum number of participants for primary prevalence estimates. The calculation yielded 384 women, to which $10 \%$ was added in anticipation of the possibility of nonresponse. The final sample size calculated was 422 women.

Participant selection was based on the pyramidal structure of Cuba's health system, in which primary care is delivered at the municipal level. Each municipality is served by one or more polyclinics (staffed with primary care specialists), to which a variable number of family doctor-and-nurse offices (CMF) report.
Together the polyclinic and CMFs provide primary care to the polyclinic catchment area, known as the health area.[24] The twostage cluster sampling included health areas as primary selection units and CMFs as secondary units.

Two health areas were selected in each municipality and within them three of the CMFs closest to the polyclinic, and which had adequate conditions for blood sample extraction. Due to the demographic similarity among health areas, this discretionary selection due to feasibility reasons does not introduce any apparent selection bias. At CMFs, the family physician and nurse invited all women within the established age range, and explained the objectives and content of the study.

The final number of women eligible to participate was 411 , lower than the number initially calculated, but still higher than the 384 needed to ensure accuracy and reliability. Of these 411, 20 were eliminated by exclusion criteria listed below. The final sample had 391 participants.

Inclusion and exclusion criteria Women aged 18-40 years living in the selected health areas were included. Pregnant women, postpartum or having delivered less than six months before and women with sickle cell disease or those treated for hematological disorders were excluded. Also excluded were those experiencing an acute disease, or chronic diseases such as cancer, diabetes mellitus, hypertension, severe asthma, chronic obstructive pulmonary disease or renal failure.

Variables Table 1 summarizes the variables used and their indicators.

Procedures Biochemistry Anemia was assessed by $\mathrm{Hb}$ concentration in whole blood; iron deficiency by serum ferritin concentration; and inflammation by serum CRP (using the high sensitivity test), AGP and serum IL-6. Testing was carried out in the Nutritional Anemia Laboratory of the National Institute of Hygiene, Epidemiology and Microbiology (INHEM) by trained personnel, using reference material marketed and distributed in Cuba for quality control. The equipment used was calibrated by Cuba's National Measurement Standards Research Institute.

Blood was extracted by antecubital venipuncture; $6 \mathrm{~mL}$ of whole blood was collected; $1 \mathrm{~mL}$ used for blood count and $5 \mathrm{~mL}$ for serum. Samples to determine $\mathrm{Hb}$ were analyzed on the day of extraction and serum was stored at $-40{ }^{\circ} \mathrm{C}$ until being analyzed for ferritin and inflammation indicators.

$\mathrm{Hb}$ was determined with hematological analyzer ABX Micros 60 (Horiba, France). Ferritin and inflammation indicators determined by ELISA, using the Cloud-Clone Corp kit (USCN Life Science Inc., USA). Because not enough reagents were available for analyzing all samples, IL-6 was assessed in a discretionary subsample of 96 participants.

H. pylori infection The ${ }^{13} \mathrm{C}$-urea breath test was used to detect $H$. pylori infection,[28] Measurements were performed using the IRIS infrared isotope analyzer (Wagner Analysen Technik GmbH, Germany).

Anthropometrics Nutritional status was assessed by measurements of weight, height and minimum waist circumference 
Table 1: Variables, indicators and cutoff points

\begin{tabular}{|c|c|c|}
\hline Variable & Indicator & Cutoff point \\
\hline \multicolumn{3}{|l|}{ Biochemistry } \\
\hline Anemia[25] & $\mathrm{Hb}(\mathrm{g} / \mathrm{L})$ & $\begin{array}{l}\text { Yes }<120 \\
\text { No } \geq 120\end{array}$ \\
\hline Severity of anemia26] & $\mathrm{Hb}(\mathrm{g} / \mathrm{L})$ & $\begin{array}{l}\text { Severe }<80 \\
\text { Moderate } 80-109 \\
\text { Mild 110-119 }\end{array}$ \\
\hline $\begin{array}{l}\text { Anemia as a public health } \\
\text { problem[25] }\end{array}$ & $\%$ of population & $\begin{array}{l}\text { Severe } \geq 40 \\
\text { Moderate } 20-39.9 \\
\text { Mild } 5-19.9 \\
\text { Not a public health problem: }<5\end{array}$ \\
\hline Iron deposit deficit[25,27] & Ferritin $(\mu \mathrm{g} / \mathrm{L})$ & $\begin{array}{l}\text { Deficit: }<15 \\
\text { Adequate: } \geq 15\end{array}$ \\
\hline \multirow{3}{*}{ Inflammation } & C-reactive protein-hs (mg/L) & $>5[25]$ \\
\hline & Alpha 1 glycoprotein (g/L) & $>1[25]$ \\
\hline & IL-6 & $\begin{array}{l}\text { No reference values or cutoff } \\
\text { points available[8] }\end{array}$ \\
\hline H. pylori infection[28] & DOB $(\%)$ & $\begin{array}{l}\text { Negative }<4 \\
\text { Positive } \geq 4\end{array}$ \\
\hline
\end{tabular}

Anthropometrics Chronic caloric malnutrition and

Nutritional status[29] $\quad$ BMI $\mathrm{kg} / \mathrm{m}^{2}[30,31]$

\begin{tabular}{|c|c|c|}
\hline & & $\begin{array}{l}\text { Obese } \geq 30.0 \\
\text { Excess body weight } \geq 25\end{array}$ \\
\hline Central adiposity & $\begin{array}{l}\text { Waist circumference }(\mathrm{cm}) \\
{[32]}\end{array}$ & $\begin{array}{l}\text { No risk }<80 \\
\text { Increased risk } 80-88 \\
\text { Very high risk }>88\end{array}$ \\
\hline \multicolumn{3}{|l|}{ Diet } \\
\hline $\begin{array}{l}\text { Intake frequency of iron-rich } \\
\text { foods and absorption } \\
\text { enhancers (groups of meat } \\
\text { products, vegetables, fruits) }\end{array}$ & $\begin{array}{l}\text { Consumption frequency for } \\
\text { foods in each group }\end{array}$ & $\begin{array}{l}\text { Foods consumed: } \\
\geq 4 \text { foods vs. }<4 \\
\text { Frequency (per week): } \\
\geq 1^{\text {a }} \text { vs. }<1^{\text {b }}\end{array}$ \\
\hline
\end{tabular}

a1-2 times weekly to daily $\quad{ }^{b}$ never to $1-3$ times monthly BMI: body mass index

DOB: delta over baseline (differential) of ${ }^{13} \mathrm{C} /{ }^{12} \mathrm{C}$ ratio of expired $\mathrm{CO}_{2}$

according to the standardized protocol of the International Biological Program.[29] Body mass index (BMI) was calculated by the Quetelet formula: weight in $\mathrm{kg} /$ (height in $\mathrm{m})^{2}$ (Table 1). $[30,31]$

Food intake indicators Dietary assessment employed a 30day recall food frequency questionnaire inquiring about foods rich in hemic (meat, viscera and blood products) and nonheme iron (eggs and legumes) foods one month prior to the study. Iron absorption enhancers, such as vegetables and fruits with significant vitamin $\mathrm{C}$ content, were assessed. The food groups assessed for associations with iron-deficiency were:

- meat products (pork liver, chicken liver, other organs, blood sausage, Italian sausage, ham, pork, red meats, poultry, fish, seafood, sources of hemic iron);

- eggs;

- beans (black, red or white);

- vegetables (lettuce, tomato, carrot, bell pepper, green beans, watercress, chard, cabbage, cucumber, spinach); and

- fruits (papaya, guava, mango, banana, pineapple).

Women who consumed fewer than four of these foods at least once a week were considered at risk for iron deficiency.

The number of foods in each group (meats, vegetables and fruits) eaten infrequently (1-2 times a week) to daily were counted for everyone. Consumption frequency was classified as:[33]
- never (not eaten during the entire period),

- very infrequent (1-3 times/month),

- infrequent (1-2 times/week),

- frequent ( $\geq 3$ times/week; because of liver's high iron content, at least once a week was considered frequent), and

- daily.

Consumption frequency was dichotomized as at least once a week (infrequent to daily) and less than once a week (never and very infrequent).

Data collection and analysis $A$ database was prepared with data for all indicators of the variables studied. Statistical programs SPSS 20.0 and Epi Info 7.1.2.0 were used. Means and SD were calculated for indicators of biochemical and anthropometric variables. Biochemical indicators that were not normally distributed (such as $\mathrm{Hb}$, ferritin, CRP, AGP and IL-6) were transformed logarithmically and their geometric mean and SD calculated. For variables that did not normalize even after transformation, the median and 25th and 75th percentiles were used.

Ferritin values were corrected for inflammation using the factors proposed by Thurnham for increases in CRP (0.77), AGP (0.75) or both (0.53). [34] Inflammation was assumed when at least one of CRP or AGP was elevated.

Overweight and obesity were grouped as excess body weight for analysis of anthropometric results. Classification based on waist circumference was used to assess central adiposity, considering that high adiposity includes increased and very increased (cardiovascular) risk cutoff points.[32]

The Mann-Whitney test was used to compare biochemical indicator means between groups infected with $H$. pylori, with a significance threshold of $p<0.05$.

Dependent variables were anemia and iron deficiency. Independent variables were inflammation, $H$. pylori infection, obesity, central adiposity, and consumption of iron-rich foods (with their respective indicators). For association analysis, variables were categorized into two or more levels and an odds ratio (OR) with 95\% confidence interval was used.

Ethics Written informed consent was obtained from each participant. The study adhered to the principles of the Declaration of Helsinki[35] and was approved by the ethics committees of the Center for Nutrition and Food Hygiene and INHEM.

\section{RESULTS}

Of the women studied, $24.6 \%(95 \% \mathrm{Cl} 20.3-28.9)(96 / 391)$ had anemia: mild in $62.5 \%(60 / 96)$ and moderate in $37.5 \%$ $(36 / 96)$. Iron deficiency was found in $68 \%(266 / 391)$ of participants and in $82.3 \%$ (79/96) of those with anemia. There 
was a significant association between iron deficiency and anemia (OR 2.68, 95\% Cl 1.51-4.77).

Table 2 shows the medians, $25^{\text {th }}$ and 75 th percentiles, and value ranges for $\mathrm{Hb}$ and ferritin, both with asymmetric distributions even after logarithmic transformation. More than $50 \%$ of participants had ferritin values indicating iron deficit. The table also displays geometric means, quartiles and value ranges for the other biochemical and anthropometric indicators (the latter with means and SD).

Prevalence of inflammation was 8.4\% (33/391) and $19.9 \%$ (78/391), assessed by CRP and AGP, respectively. Some $73.1 \%$ (286/391) had normal values of both CRP and AGP; $25.3 \%(99 / 391)$ had one of these indicators elevated, and $1.5 \%(6 / 391)$ had both.

Nutritional status based on BMI could not be assessed in 3 women who did not appear for physical measurements. In the remaining 388, normal nutritional status predominated in 53.3\% (207/388). However, $38.7 \%(150 / 388)$ had excess body weight and $26.7 \%(101 / 378)$, increased central adiposity; $8 \%$ (31/388) were underweight. It was impossible to assess central adiposity in 10 women: 8 aged 19 years because there are no reference values for their age group, and 2 who appeared for measurement when the needed specialist was absent.

Prevalence of $H$. pylori infection was $47.1 \%$ (184/391). No significant differences were found between groups with and without infection in mean $\mathrm{Hb}(p=0.939)$, ferritin $(p=0.180)$, CRP $(p=0.313)$, AGP $(p=0.597)$ or IL-6 $(p=0.671)$ (Table 3).

Table 4 shows positivity for inflammation markers (CRP and AGP), independently and in combination, in women with and without risk factors $(H$. pylori infection, excess body weight and central adiposity). It also displays ORs (with 95\% confidence intervals) reflecting associations between risk factors and inflammation markers. Excess body weight and central adiposity exhibited significant associations with CRP; there were no significant associations with AGP.

Table 5 shows frequency of food consumption in two complementary categories, at least once a week and less than once a week. The most frequently consumed meat products were poultry $(81.9 \%)$, ham $(64.4 \%)$ and pork $(63.6 \%)$; viscera were consumed at least weekly by fewer than $10 \%$ of respondents. Among nonheme iron sources, the most frequently consumed were eggs and beans, consumed at least weekly by $75.8 \%$ and $61.1 \%$, respectively. Tomatoes were the most frequently consumed vegetable, eaten by $82.2 \%$ at least weekly; $<40 \%$ of respondents consumed the remaining vegetables at least
Table 2: Biochemical and anthropometric indicators to assess anemia, iron deficiency, inflammation and nutritional status in women of childbearing age, Cuba, 2014

\begin{tabular}{|c|c|c|c|c|c|c|}
\hline Biochemistry & $\begin{array}{l}\text { Geometric } \\
\text { mean (SD) }\end{array}$ & Min & $\operatorname{Max}$ & $\mathbf{P}_{25}$ & Median & $\mathbf{P}_{75}$ \\
\hline $\mathrm{Hb}(\mathrm{g} / \mathrm{L})(\mathrm{n}=391)$ & - & 80.00 & 152.00 & 120.00 & 127.00 & 132.00 \\
\hline Ferritin $(\mu \mathrm{g} / \mathrm{L})^{*}(\mathrm{n}=391)$ & - & 0.20 & 303.64 & 3.62 & 9.60 & 19.03 \\
\hline $\mathrm{CRP}(\mathrm{mg} / \mathrm{L})(\mathrm{n}=391)$ & $0.90(3.49)$ & 0.03 & 20.90 & 0.39 & 0.84 & 2.40 \\
\hline AGP $(g / L)(n=391)$ & $0.80(1.36)$ & 0.36 & 2.44 & 0.64 & 0.78 & 0.95 \\
\hline IL-6 (ng/L) (n = 96) & $0.33(1.88)$ & 0.14 & 5.59 & 0.20 & 0.28 & 0.48 \\
\hline Anthropometrics & mean (SD) & Min & Max & $\mathbf{P}_{25}$ & Median & $P_{75}$ \\
\hline BMI $(n=388)$ & $24.4(5.3)$ & 14.8 & 51.8 & 20.7 & 23.5 & 27.4 \\
\hline $\begin{array}{l}\text { Waist circumference }(\mathrm{cm}) \\
(\mathrm{n}=386)\end{array}$ & $74.8(10.3)$ & 54.8 & 122.4 & 67.6 & 73.2 & 80.2 \\
\hline
\end{tabular}

corrected for inflammation

$\mathrm{Hb}$ : hemoglobin

Table 3: Biochemical indicators in women of childbearing age with and without H. pylori infection, Cuba, 2014 ( $n=391$ )

\begin{tabular}{lr|}
$\begin{array}{l}\text { Biochemical } \\
\text { indicator }\end{array}$ & $\begin{array}{r}\text { H. pylori +ve } \\
\text { Mean (SD) }\end{array}$ \\
\hline $\mathrm{Hb}(\mathrm{g} / \mathrm{L})$ & $125.4(10.8)$ \\
\hline Ferritin $(\mu \mathrm{g} / \mathrm{L})$ & $15.9(25.3)$ \\
CRP $(\mathrm{mg} / \mathrm{L})$ & $1.8(2.5)$ \\
AGP $(\mathrm{g} / \mathrm{L})$ & $0.8(0.3)$ \\
\hline IL-6* $(\mathrm{ng} / \mathrm{L})$ & $0.4(0.3)$
\end{tabular}

${ }^{*} \mathrm{n}=96$

AGP: alpha 1-acid glycoprotein

IL-6: interleukin-6

BMI: Body mass index BMI: Body mass inde
IL-6: interleukin-6

CRP: C-reactive protein P25: 25th percentile
Table 4: Anemia risk factor prevalence and association with inflammation markers in women of childbearing age, Cuba, 2014

\begin{tabular}{|c|c|c|c|c|c|c|}
\hline \multirow{3}{*}{ Risk Factor } & \multicolumn{6}{|c|}{ Marker } \\
\hline & \multicolumn{2}{|c|}{ CRP } & \multicolumn{2}{|c|}{ AGP } & \multicolumn{2}{|r|}{ Both } \\
\hline & $\begin{array}{c}\text { Prev } \\
\%\end{array}$ & $\begin{array}{c}\text { OR } \\
(95 \% \mathrm{Cl})\end{array}$ & $\begin{array}{c}\text { Prev } \\
\%\end{array}$ & $\begin{array}{c}\text { OR } \\
(95 \% \mathrm{CI})\end{array}$ & $\begin{array}{c}\text { Prev } \\
\%\end{array}$ & $\begin{array}{c}\text { OR } \\
(95 \% \mathrm{Cl})\end{array}$ \\
\hline H. pylori $(+)^{a}$ & 6.5 & \multirow{2}{*}{$\begin{array}{r}0.62 \\
(0.30-1.29)\end{array}$} & 17.9 & \multirow{2}{*}{$\begin{array}{r}0.79 \\
(0.48-1.30)\end{array}$} & 23.9 & \multirow{2}{*}{$\begin{array}{r}0.68 \\
(0.43-1.06)\end{array}$} \\
\hline H. pylori $(-)^{\mathrm{a}}$ & 10.1 & & 21.7 & & 29.5 & \\
\hline Excess body weight $(+)^{b}$ & 14.7 & \multirow{2}{*}{$\begin{array}{r}3.55 \\
(1.67-7.55)\end{array}$} & 18.6 & \multirow{2}{*}{$\begin{array}{r}0.83 \\
(0.49-1.39)\end{array}$} & 30.0 & \multirow{2}{*}{$\begin{array}{r}1.23 \\
(0.78-1.95)\end{array}$} \\
\hline Excess body weight $(-)^{b}$ & 3.9 & & 21.0 & & 25.2 & \\
\hline Central adiposity $(+)^{c}$ & 15.8 & \multirow{2}{*}{$\begin{array}{r}2.67 \\
(1.28-5.57)\end{array}$} & 22.8 & \multirow{2}{*}{$\begin{array}{r}1.28 \\
(0.73-2.22)\end{array}$} & 35.6 & \multirow{2}{*}{$\begin{array}{r}1.77 \\
(1.08-2.90)\end{array}$} \\
\hline Central adiposity (-) & 6.1 & & 19.1 & & 24.2 & \\
\hline
\end{tabular}

${ }^{a} n=391 \quad{ }^{b} n=388 \quad{ }^{c} n=378 \quad$ AGP: alpha 1-acid glycoprotein $\quad$ CRP: C-reactive protein

weekly. Bananas were eaten at least weekly by $61.8 \%$ of women, but less than half (in some cases less than a third) ate any of the other fruits that frequently.

Analysis of the association between inflammation and iron deficiency resulted in OR $1.72(95 \% \mathrm{Cl} 1.03-2.87)$, while the association between inflammation and anemia was significant but in the opposite direction: OR 0.55 (95\% Cl 0.31-0.98). No association was found between $H$. pylori and anemia (OR $0.94,95 \%$ Cl 0.59-1.49) or low ferritin (OR 0.75, 95\% Cl 0.491.14). Excess body weight was not positively associated with iron deficiency or anemia, but central adiposity had significant protective associations in both cases (OR $0.54,95 \% \mathrm{Cl}$ $0.33-0.89$ and $\mathrm{OR} 0.44,95 \% \mathrm{Cl} 0.24-0.82$, respectively). No significant associations were found between consumption frequency of any food and anemia or iron deficiency (all OR confidence intervals included unity) (Table 6). 
Table 5: Consumption of iron-rich foods and absorption enhancers in women of childbearing age, Cuba, $2014(n=343)$

\begin{tabular}{|c|c|c|}
\hline \multirow{2}{*}{ Food } & \multicolumn{2}{|c|}{ Weekly consumption } \\
\hline & $<1(\%)$ & $\geq 1(\%)$ \\
\hline Pork liver & 93.6 & 6.4 \\
\hline Chicken Liver & 98.0 & 2.0 \\
\hline Other organs & 99.1 & 0.9 \\
\hline Blood sausage & 99.1 & 0.9 \\
\hline Italian sausage & 93.0 & 7.0 \\
\hline Ham & 35.6 & 64.4 \\
\hline Pork & 36.4 & 63.6 \\
\hline Mutton & 94.2 & 5.8 \\
\hline Beef & 78.7 & 21.3 \\
\hline Poultry & 18.1 & 81.9 \\
\hline Fish & 79.3 & 20.7 \\
\hline Seafood & 95.0 & 5.0 \\
\hline Eggs & 24.2 & 75.8 \\
\hline Beans & 30.9 & 69.1 \\
\hline Lettuce & 79.6 & 20.4 \\
\hline Tomato & 17.8 & 82.2 \\
\hline Carrot & 82.8 & 17.2 \\
\hline Bell pepper & 84.0 & 16.0 \\
\hline Green beans & 79.9 & 20.1 \\
\hline Watercress & 95.9 & 4.1 \\
\hline Chard & 89.8 & 10.2 \\
\hline Cabbage & 60.1 & 39.9 \\
\hline Cucumber & 65.3 & 34.7 \\
\hline Spinach & 96.5 & 3.5 \\
\hline Papaya & 85.1 & 14.9 \\
\hline Guava & 65.9 & 34.1 \\
\hline Mango & 87.2 & 12.8 \\
\hline Banana & 38.2 & 61.8 \\
\hline Pineapple & 81.3 & 18.7 \\
\hline
\end{tabular}

Table 6: Association of inflammation, $\boldsymbol{H}$. pylori infection, excess body weight and obesity with anemia and iron deficiency in women of childbearing age, Cuba, 2014

\begin{tabular}{|c|c|c|c|c|}
\hline Variable & $\begin{array}{l}\text { Positive } \\
(\%)\end{array}$ & $\begin{array}{l}\text { Negative } \\
(\%)\end{array}$ & $\begin{array}{l}\text { Iron deficit }^{a} \\
(n=391) \\
\text { OR }(95 \% \mathrm{Cl})\end{array}$ & $\begin{array}{c}\text { Anemia }^{\mathrm{b}} \\
(\mathrm{n}=391) \\
\text { OR }(95 \% \mathrm{Cl})\end{array}$ \\
\hline $\begin{array}{l}\text { Inflammation } \\
(\mathrm{n}=391)\end{array}$ & 26.9 & 73.1 & $\begin{array}{r}1.72 \\
(1.03-2.87)\end{array}$ & $\begin{array}{r}0.55 \\
(0.31-0.98)\end{array}$ \\
\hline $\begin{array}{l}\text { H. pylori } \\
(\mathrm{n}=391)\end{array}$ & 47.1 & 52.9 & $\begin{array}{r}0.75 \\
(0.49-1.14)\end{array}$ & $\begin{array}{r}0.94 \\
(0.59-1.49)\end{array}$ \\
\hline $\begin{array}{l}\text { Excess body } \\
\text { weight } \\
(n=388)\end{array}$ & 38.7 & 61.3 & $\begin{array}{r}0.65 \\
(0.41-1.04)\end{array}$ & $\begin{array}{r}0.65 \\
(0.38-1.11)\end{array}$ \\
\hline $\begin{array}{l}\text { Central adiposity } \\
(\mathrm{n}=378)\end{array}$ & 26.7 & 73.3 & $\begin{array}{r}0.54 \\
(0.33-0.89)\end{array}$ & $\begin{array}{r}0.44 \\
(0.24-0.82)\end{array}$ \\
\hline \multicolumn{5}{|c|}{ Deficit in iron-rich food consumption ( $n=343$ ) } \\
\hline Meat products & 5.0 & 95.0 & $\begin{array}{r}1.17 \\
(0.68-2.02)\end{array}$ & $\begin{array}{r}1.02 \\
(0.32-3.24)\end{array}$ \\
\hline Eggs & 24.2 & 75.8 & $\begin{array}{r}1.08 \\
(0.62-1.87)\end{array}$ & $\begin{array}{r}1.69 \\
(0.97-2.93)\end{array}$ \\
\hline Legumes & 30.9 & 69.1 & $\begin{array}{r}0.69 \\
(0.42-1.13)\end{array}$ & $\begin{array}{r}1.10 \\
(0.64-1.89)\end{array}$ \\
\hline Vegetables & 12.0 & 88.0 & $\begin{array}{r}1.36 \\
(0.82-2.25)\end{array}$ & $\begin{array}{r}1.56 \\
(0.76-3.18)\end{array}$ \\
\hline Fruits & 15.2 & 84.8 & $\begin{array}{r}0.74 \\
(0.40-1.38)\end{array}$ & $\begin{array}{r}1.22 \\
(0.62-2.39)\end{array}$ \\
\hline
\end{tabular}

aferritin $<15 \mu \mathrm{g} / \mathrm{L}$ ( $68 \%$ of sample) $\quad{ }^{\text {bhemoglobin }}<120 \mathrm{~g} / \mathrm{L}$ ( $24.6 \%$ of sample)

\section{DISCUSSION}

The anemia prevalence we found is consistent with earlier estimates in Cuba[2,17] and comparable to that of some other countries in the Americas and the Caribbean Region such as Guatemala, Brazil, Dominican Republic and Bolivia, where prevalence ranges from $21.4 \%$ to $38.3 \%$.[36] However, other studies have found lower prevalence. For example, anemia prevalence was $16.7 \%$ in a national sample of women aged 1935 years in Mexico in 2006,[37] and a study in Chile from 19812010 found $9.6 \%$ in the first year and $10 \%$ in 2010.[38] Although our study was carried out in only 4 municipalities of Havana and is not representative of the city or the country, Cuba's relative demographic, cultural and socioeconomic homogeneity suggests that our estimates should not differ greatly from those derived from a more comprehensive sampling.

In 2014, Kassebaum published a systematic analysis of the global burden of anemia from 1990 to 2010 and found that in the Caribbean region, iron deficiency was the leading cause of anemia in both sexes. The following causes among women, in order of importance, were sickle cell disease, Ancylostoma spp. infection and uterine fibroid.[39]

In our study population, iron deficiency was an important factor in anemia and was found to be related to inflammation. In contrast, a negative risk association was observed between inflammation and anemia.

Current evidence suggests an association between inflammation and anemia, although the strength of the association appears to be lower than that found for specific micronutrients, such as iron, mainly in preschool groups.[7] This was a cross-sectional study and timing might have affected findings. Erythrocytes have an average life span of 120 days, and anemia is the last stage of iron deficiency, CRP and AGP indicate subclinical inflammation. CRP peaks in circulation 48-72 hours after an inflammatory injury and then declines, and AGP peaks in 3-5 days,[27] so the effects of inflammation on anemia cannot be observed in early stages (unlike ferritin, which is the first indicator of iron depletion). A physiological response to inflammation can appear quickly, allowing the body to remain healthy and in homeostasis, preventing mobilization of iron from tissues and using the scarce iron absorbed directly from food for $\mathrm{Hb}$ synthesis, before developing anemia. Median $\mathrm{Hb}$ found in this study is close to the cutoff point for anemia, so that a precarious iron balance may exist in the body preceding development of anemia a short time afterwards. This may also indicate the influence of other factors on iron deficiency and anemia, such as heavy menstrual periods. $[40,41]$

Assessment of nutritional status showed that over one third of participants had excess body weight. This proportion is similar to those found in Mexico (35.5\%)[37] and Colombia (42.3\%),[42] but lower than that detected in Cuba's Third National Survey on Risk Factors and Chronic Diseases (ENFRENT III, 2010-2011), which found excess body weight in $48.3 \%$ of women aged $\geq 15$ years.[43] Studies in LMIC have revealed an association between anemia and obesity, $[36,44,45]$ which may be explained by the inflammatory action of adipose tissue. However, we found no such association. On the contrary, a trend to lower prevalence of anemia and iron deficiency with increased BMI was observed, similar to findings by Kordas,[42] Qin[46] and 
Wendt,[11] in which women with excess body weight were less likely to have anemia or iron deficiency than those with normal weight. One explanation may be that overweight women have generally ingested more food, including those rich in iron and absorption enhancers.[46]

Another aspect to consider is that increased central adiposity and excess body weight were associated with CRP-expressed inflammation more strongly than with AGP, so when assessed jointly, the level of the association is weakened.

BMI has limitations as an indicator of adiposity, and waist circumference may be a better marker of total body fat composition. Obesity with normal weight has been defined as excess fat with normal BMI, and this condition has been associated with early inflammation. Marqués Vidal found fat percentage above the 66th percentile with normal CRP values in $5.4 \%$ of a group of women with BMI <25.[47] Cuba's ENFRENT III found $51.5 \%$ of women aged $\geq 15$ years had increased risk and very increased risk of central adiposity, as indicated by waist circumference-much higher than the one found in this study — but did not assess biochemical indicators of inflammation.[43]

H. pylori infection was frequent in our study population, but not associated with iron deficiency or anemia. The sample did not include women with symptoms of digestive disorders, so it may be that asymptomatic $H$. pylori colonization (i.e., without ulcers or gastritis) does not produce iron absorption disorders and anemia, nor increase inflammation indicators. Previous studies in other Latin American countries (Argentina, Brazil, Mexico, Bolivia, and Venezuela) also found no associations between $H$. pylori and ferritin or soluble transferrin receptor concentrations, leading authors to conclude that there is no evidence in the region supporting the hypothesis that $H$. pylori infection contributes to anemia or iron deficiency.[15]

The food frequency questionnaire is useful for estimating usual food intake. The diet consumed by women in our study reflects lack of diversity in food selection, which was also found in previous studies in groups of children and persons aged $>15$ years, with a similar pattern of behavior throughout Cuba and with low intake of $\mathrm{A}$ and $\mathrm{B}$-complex vitamins and iron, among other nutrients. $[48,49]$

The absence of a significant association between food consumption frequency and either iron deficiency or anemia may in part be due to the multiplicity of factors that affect nutrient absorption and digestion, which also depend on prior nutritional status.[50] Thus, dietary intake is a limited indicator of individual nutritional status. Furthermore, the food frequency questionnaire does not ask about quantities, so we could not estimate actual amounts of iron ingested.

The US National Health and Nutrition Examination Survey also used the 30-day food frequency questionnaire, in nonpregnant Mexican-American and non-Hispanic white women aged 12-39 years (1988-1994), and found that, contrary to expectations, dietary intake patterns of iron-containing foods did not explain the study group's low iron levels.[51]
Some methodological differences must be considered when comparing our results with others, particularly the use of different cutoff points. While we used Thurnham and WHO's recommended CRP cutoff points, $[27,34]$ especially to correct for ferritin levels, other authors have assessed inflammation using different cutoff points-for example, that recommended by the American Heart Association (CRP $>3 \mathrm{mg} / \mathrm{L}$ ) for assessment of obesity and adiposity.[11,52] Gartner's study of 811 Moroccan women used CRP $>2 \mathrm{mg} / \mathrm{L}$ relative to ferritin value increases;[53] and Lourenço used $1 \mathrm{mg} / \mathrm{L}$.[54] The question of optimal cutoff points is one that should be addressed in future population studies.

One study limitation is its cross-sectional design, which does not allow causal inference, because it could not establish chronological order of obesity, inflammation and $H$. pylori with respect to anemia and iron deficit. Another was the practical infeasibility of studying other nutritional factors for anemia and iron deficiency, thus limiting our ability to control for potential confounders. One such variable is menorrhagia, which should be included in future research.

The study did not confirm the expectation of a positive association between anemia and inflammation (measured by two of its markers), central adiposity or excess body weight. The most plausible explanation is the so-called "collision bias" that occurs when assessing association between two variables with a common cause.[55] If, for example, there are factors underlying inflammation, adiposity and excess body weight that also have a causal relationship to anemia, measurement of the association between anemia and each of the three risk factors would be biased, even in the opposite direction, which seems to have happened in this study.

Despite its design limitations and the inability to control some variables and risk factors, this study provides information unavailable thus far in Cuba for an important population group: women of childbearing age.

\section{CONCLUSIONS}

Anemia was shown to be a moderate public health problem in the studied group, but with iron deficiency present in two thirds of participants and associated with anemia. Risk factors for anemia and iron deficiency, such as menorrhagia and bacterial or viral infections, should be assessed in women of childbearing age, to support interventions needed to reduce risks in pregnancy and childbirth.

\section{ACKNO WLEDGMENTS}

The authors would like to thank Iris Cortina Mena MD (Provincial Hygiene Epidemiology and Microbiology Center, Havana), Ahindris Calzadilla Cámbara MD, family physician (INHEM), Zuleimi Guerra Montané (Department of Biochemistry and Physiology, INHEM) and Cornelia Loechl, PhD (International Atomic Energy Organization, Vienna) for their support in implementing the study, including sample collection.

\section{FUNDING}

The study was funded by Cuba's Ministry of Public Health (National Project 14-1-098) and by the International Atomic Energy Organization (IAEA-Coordinated Research Project E4.30.25). - /1- 


\section{REFERENCES}

1. World Health Organization. The global prevalence of anaemia in 2011 [Internet]. Geneva: World Health Organization; 2015 [cited 2016 Nov 8]. 43 p. Available from: http://apps.who.int/ iris/bitstream/10665/177094/1/9789241564960 eng.pdf?ua $=1$

2. De Benoist B, McLean E, Egli I, Cogswell M, editors. Worldwide prevalence of anaemia 1993-2005: WHO global database on anaemia. Geneva: World Health Organization Press; 2008. $40 \mathrm{p}$.

3. López de Romaña D. Situación actual de los micronutrientes en Latinoamérica: Prevalencia de su deficiencia y programas nacionales de entrega de micronutrientes [Internet]. Presentation at 1er Evento para la Fortificación del Arroz en América Latina y el Caribe; 2016 Aug 10-12; Santo Domingo, Dominican Republic. Waldkirch (DE): Burger Druck; 2016 [cited 2016 Oct 28]. 28 p. Available from: http://es.wfp.org/sites/default/ files/es/file/1_situacion_actual_de_los_micronu trientes_en_latinoamerica.pdf. Spanish.

4. Thurnham DI, Northrop-Clewes CA. Infection in the etiology of anemia. In: Kraemer K, Zimmermann MB, editors. Nutritional Anemia. Basel $(\mathrm{CH})$ : Sight and Life Press; 2007. p. 231-56.

5. Northrop-Clewes CA, Thurnham DI. Biomarkers for the differentiation of anemia and their clinical usefulness. J Blood Med. 2013 Mar 20;4:11-22.

6. McLean E, Cogswell M, Egli I, Wojdyla D, de Benoist B. Worldwide prevalence of anaemia, WHO Vitamin and Mineral Nutrition Information System. 1993-2005. Public Health Nutr. 2009 Apr;12(4):444-54

7. Raiten DJ, Sakr Ashour FA, Ross AC, Meydani SN, Dawson HD, Stephensen CB, et al. Inflammation and Nutritional Science for Programs/ Policies and Interpretation of Research Evidence (INSPIRE). J Nutr [Internet]. 2015 May [cited 2015 Jul 13];145(5):1039-1108. Available from: http://jn.nutrition.org/content/145/5/1039S.full .pdf+html

8. Nairz M, Haschka D, Demetz E, Weiss G. Iron at the interface of immunity and infection. Front Pharmacol [Internet]. 2014 Jul 16 [cited 2015 May 4];5(152). Available from: https:// www.researchgate.net/profile/Guenter_Weiss/ publication/264394576_Iron_at_the_interface of immunity_and_infection/links/54ae $2 \mathrm{~b} 020$ cf2213c5fe4217c

9. Abbaspour N, Hurrell R, Kelishadi R. Review on iron and its importance for human health. J Res Med Sci [Internet] 2014 Feb [cited 2014 Jun 20];19(2):164-74. Available from: http://www .ncbi.nlm.nih.gov/pmc/articles/PMC3999603/\#

10. Becker C, Orozco M, Solomons NW, Schümann K. Iron metabolism in obesity: How interaction between homoeostatic mechanisms can interfere with their original purpose. Part I: Underlying homeostatic mechanisms of energy storage and iron metabolisms and their interaction. $\mathrm{J}$ Trace Elemen Med Biol [Internet]. 2015 Apr [cited 2015 Jul 21];30:195-201. Available from: http://www.sciencedirect.com/science/article/pii/ S0946672X14001916?via\%3Dihub

11. WendtAS, Jefferds ME, Perrine CG, Halleslevens $\mathrm{P}$, Sullivan KM. Overweight and obese women less likely to have low serum ferritin, Nicaragua. Public Health Nutr. 2015 Mar;18(4):736-41.

12. Mohamed-Ali V, Gooddrick S, Rawesh A, Katz DR, Miles JM, Yudkin JS, et al. Subcutaneous adipose tissue releases interleukin-6, but not tumor necrosis factor-alpha, in vivo. J Clin Endocrinol Metab. 1997 Dec;82(12):4196-200.

13. Gómez Ramírez S, Martín Montañez E, Muñoz Gómez M. Infección por Helicobacter pylori, deficiencia de hierro y anemia. Anemia. 2010;3(3):111-21. Spanish.
14. López de Romaña D, Pizarro F, Diazgranados D, Barba A, Olivares M, Brunser O. Effect of Helicobacter pylori infection on iron absorption in asymptomatic adults consuming wheat flour fortified with iron and zinc. Biol Trace Elem Res. 2011 Dec;144(1-3):1318-26.

15. Santos IS, Boccio J, Davidsson L, HernándezTriana M, Huanca-Sardinas E, Janjetic M, et al. Helicobacter pylori is not associated with anaemia in Latin America: results from Argentina, Brazil, Bolivia, Cuba, Mexico and Venezuela. Public Health Nutr. 2009 Oct;12(10):1862-70.

16. Clark SF. Iron deficiency anemia. Nutr Clin Pract. 2008 Apr-May;23(2):128-41.

17. Jiménez S, Pita G, Padrón $M$. La anemia por deficiencia de hierro. Aspectos generales para su prevención y control. Manual de capacitación para el equipo de salud. Havana: Institute of Nutrition and Food Hygiene and (CU); World Food Program; 2009. Spanish.

18. World Health Organization. Plan de aplicación integral sobre nutrición materna, del lactante y del niño pequeño [Internet]. Geneva: World Health Organization; 2014 [cited 2016 Aug 19]. 22 p. Available from: http://apps.who.int/ iris/bitstream/10665/130456/1/WHO NMH _NHD_14.1_spa.pdf?ua=1. Spanish.

19. Jiménez-Acosta SM, Rodríguez-Suárez A, PitaRodríguez G. Prevalencia de anemia durante el embarazo en Cuba. Evolución en 15 años. Rev Española Nutr Comunitaria. 2014;20(2):42-7. Spanish.

20. Nutrition and Food Hygiene Center (CU). Informe técnico sobre situación nutricional de poblaciones de riesgo. Havana: National Institute of Hygiene, Epidemiology and Microbiology (CU); 2014. Spanish.

21. Nutrition and Food Hygiene Center (CU). Informe técnico sobre situación nutricional de poblaciones de riesgo. Havana: Institute of Nutrition and Food Hygiene; National Institute of Hygiene, Epidemiology and Microbiology (CU); 2017. Spanish.

22. National Statistics Bureau (CU). República de Cuba. Anuario estadístico 2015 [Internet]. 2016 [cited 2017 Jun 12]. Available from: http://www .one.cu/aec2015/00\%20Anuario\%20Estadis tico\%202015.pdf. Spanish.

23. National Statistics Bureau (CU). República de Cuba. Anuario estadístico 2011 [Internet]. 2012 [cited 2013 May 28]. Available from: http://www .one.cu/aec2011/datos/3.6.xls. Spanish.

24. Domínguez-Alonso E, Zacca E. Sistema de salud de Cuba. Salud Pública Méx. 2011 Jan;53 Suppl 2:S168-76. Spanish.

25. World Health Organization. Iron deficiency anemia. Assessment, prevention and control. A guide for programme managers [Internet]. Geneva: World Health Organization; 2001 [cited 2005 Dec 26]. 114 p. Available from: http://www .who.int/iris/bitstream/10665/66914/http://apps .who.int//iris/bitstream/10665/66914/1/WHO NHD 01.3.pdf?ua $=1$

26. World Health Organization. Haemoglobin concentrations for the diagnosis of anaemia and assessment of severity. Vitamin and Mineral Nutrition Information System (VMNIS) [Internet]. Geneva: World Health Organization; 2011 [cited 2013 Feb 4]; [about 6 p.]. Available from: http://apps.who.int/iris/bitstream/10665/85839/3/ WHO_NMH_NHD_MNM_11.1_eng.pdf?ua=1

27. World Health Organization; Center for Disease Control and Prevention (CDC). Assessing the iron status of population. 2nd ed. Geneva: World Health Organization Press; 2007. 108 p.

28. Barrado A, Boccio J, Valencia ME. The usefulness of stable isotopes in nutrition and human health: the application of mass spectrometry and
${ }^{13} \mathrm{C}$-breath test to detect Helicobacter pylori. Arch Latinoam Nutr. 2004 Dec;54(4 Suppl 2):S27-43. Spanish, English.

29. Weiner JS, Lourie JA, editors. Human Biology. A guide to field methods. Oxford: Blackwell Scientific Publications; 1969. $621 \mathrm{p}$.

30. Shetty PS, James WPT. Body mass index. A measure of chronic energy deficiency in adults. Rome: Food and Agriculture Organization of the United Nations; 1994. p. 57

31. Díaz Sánchez ME. Indicadores antropométricos de la evaluación nutricional. In: Alimentación, nutrición y salud. Havana: Institute of Food Hygiene and Nutrition (CU); 2011. p. 76. Spanish.

32. Han TS, van Leer EM, Seidell JC, Lean ME. Waist circumference action levels in the identification of cardiovascular risk factor: prevalence study in a random sample. BMJ. $1995 \mathrm{Nov}$ 25:311(7017):1401-5

33. Rodríguez Suárez A. Sistema Integrado para los Estudios de Consumo de Alimentos [thesis]. [Havana]: National School of Public Health (CU); 2006. Spanish.

34. Thurnham DI, McCabe LD, Haldar S, Wieringa FT, Northrop-Clewes CA, McCabe GP. Adjusting plasma ferritin concentrations to remove the effects of subclinical inflammation in the assessment of iron deficiency: a meta-analysis. Am J Clin Nutr. 2010 Sep;92(3):546-55

35. Declaración de Helsinki de la Asociación Médica Mundial. Principios éticos para las investigaciones médicas en seres humanos. 64ta Asamblea General, Fortaleza, Brasil, 2013 Oct [Internet] Madrid: Instituto de Salud Carlos III; 2013 [cited 2016 Nov 9]. 9 p. Available from: http://www .isciii.es/ISCIII/es/contenidos/fd-investigacion/ fd-evaluacion/fd-evaluacion-etica-investigacion/ Declaracion-Helsinki-2013-Esp.pdf. Spanish.

36. Mujica-Coopman MF, Brito A, López de Romaña D, Ríos-Castillo I, Cori H, Olivares M. Prevalence of Anemia in Latin America and the Caribbean. Food Nutr Bull. 2015 Jun;36(2 Suppl):S119-28.

37. Shamah-Levy T, Villalpando-Hernández S, García-Guerra A, Mundo-Rosas V, Mejía-Rodríguez F, Domínguez-Islas CP. Anemia in Mexican women: results of two national probabilistic surveys Salud Pública Mex. 2009;51 Suppl 4:S515-22.

38. Ríos-Castillo I, Brito A, Olivares M, López-de Romaña D, Pizarro F. Baja prevalencia de anemia por deficiencia de hierro entre 1981 y 2010 en mujeres chilenas en edad fértil. Salud Pública Méx [Internet]. 2013 Sep-Oct [cited 2014 Jun 21];55(5):478-83. Available from: http://www .scielo.org.mx/scielo.php?script=sci arttext\&pid =S0036-36342013000700004. Spanish.

39. Kassebaum NJ, Jasrasaria R, Naghavi M, Wulf SK, Johns N, Lozano R, et al. Systematic analysis of global anemia burden from 1990 to 2010 . Blood [Internet]. 2014 Jan 30 [cited 2014 Jun 20];123(5):615-24. Available from: http://blood journal.hematologylibrary.org/content/blood journal/123/5/615.full.pdf

40. Geissler $\mathrm{C}$, Singh M. Iron, meat and health. Nutrients. 2011 Mar;3(3):283-316.

41. James AH, Ragni MV, Picozzi VJ. Bleeding disorders in premenopausal women. another public health crisis for Hematology? American Society of Hematology Special Educational Symposium. Hematology. 2006;1:474-85.

42. Kordas K, Fonseca Centeno ZY, Pachón H Jimenez Soto AZ. Being overweight or obese is associated with lower prevalence of anemia among Colombian women of reproductive age. J Nutr. 2013 Feb;143(2):175-81.

43. Bonet Gorbea M, Varona Pérez P. Evaluación antropométrica. III Encuesta Nacional de Factores de Riesgo y Actividades Preventivas de 
Enfermedades No Transmisibles (ENFRENT III). Cuba 2010-2011. Havana: Editorial de Ciencias Médicas; 2014. p. 106-35. Spanish.

44. Eftekhari M, Mozaffari-Khosravi H, Shidfar F. The relationship between $\mathrm{BMI}$ and iron status in irondeficient adolescent Iranian girls. Public Health Nutr. 2009 Dec;12(12):2377-81.

45. Eckhardt CL, Torheim LE, Monterrubio E, Barquera S, Ruel MT. The overlap of overweight and anaemia among women in three countries undergoing the nutrition transition. Eur $\mathrm{J}$ Clin Nutr. 2008 Feb;62(2):238-46

46. Qin $Y$, Melse-Boonstra A, Pan X, Yuan B, Dai $\mathrm{Y}$, Zhao J, et al. Anemia in relation to body mass index and waist circumference among Chinese women. Nutrition J. [Internet]. 2013 [cited 2014 Nov 19];12:10. Available form: https://nutritionj.biomedcentral.com/articles/ 10.1186/1475-2891-12-10

47. Marques-Vidal P, Pécoud A, Hayoz D, Paccaud F, Mooser V, Waeber G, et al. Normal weight obesity: relationship with lipids, glycaemic status, liver enzymes and inflammation. Nutr Metab Cardiovasc Dis. 2010 Nov;20(9):669-75.

48. Pita-Rodríguez G, Jiménez-Acosta S, BasabeTuero B, Macías Matos $\mathrm{C}$, Selva Suárez L, Hernández Fernández $C$, et al. El bajo consumo de alimentos ricos en hierro y potenciadores de su absorción se asocia con anemia en preescolares cubanos de las provincias orientales. 2005-2011. Rev Chil Nutr. 2013 Sep;40(3):22434. Spanish.

49. Porrata-Maury C. Consumo y preferencias alimentarias de la población cubana con 15 y más años de edad. Rev Cubana Aliment Nutr. 2009;19(1):87-105. Spanish.

50. Hurrell R, Egli I. Iron bioavailability and dietary reference values. Am J Clin Nutr. 2010 May;91(5):1461S-7S.

51. Ramakrishnan U, Frith-Terhune A, Cogswell M, Kettel Khan L. Dietary intake does not account for differences in low iron stores among Mexican American and non-Hispanic white women: Third National Health and Nutrition Examination Survey, 1988-1994. J Nutr. 2002 May;132(5):996-1001.
52. McDade TW, Rutherford JN, Adair L, Kuzawa C Population differences in associations between C-reactive protein concentration and adiposity: comparison of young adults in the Philippines and the United States. Am J Clin Nutr. 2009 Apr;89(4):1237-45.

53. Gartner A, Berger J, Bour A, El Ati J, Traissac P, Landais $\mathrm{E}$, et al. Assessment of iron deficiency in the context of the obesity epidemic: importance of correcting serum ferritin concentrations for inflammation. Am J Clin Nutr [Internet]. 2013 Sep [cited 2014 Jun 2];98(3):821-6. Available from: http://www.ajcn.org/cgi/pmidlookup?view=long\& pmid $=23885047$

54. Lourenço BH, Cardoso MA; ACTION Study Team. C-reactive protein concentration predicts change in Body Mass Index during childhood. PLoS One [Internet]. 2014 Mar 6 [cited 2014 Jun 20];9(3):e90357. Available from: http:// www.plosone.org/article/fetchObject.action ? uri=info \%3Adoi \%2F $10.1371 \% 2 \mathrm{Fjournal}$ .pone.0090357\&representation=PDF

55. Hernán MA, Hernández-Díaz $S$, Werler MM, Mitchell AA. Causal knowledge as a prerequisite for confounding evaluation: an application to birth defects epidemiology. Am J Epidemiol. 2002 Jan 15;155(2):176-84.

\section{THE AUTHORS}

Gisela M. Pita-Rodríguez (Corresponding author: hematologia@inhem.sld.cu; gmpita@ infomed.sld.cu), physician specializing in clinical biochemistry with a master's degree in environmental health. Head, Nutritional Anemia Laboratory, National Hygiene, Epidemiology and Microbiology Institute (INHEM), Havana, Cuba.

Beatriz Basabe-Tuero, biochemist with a master's degree in public health nutrition and doctorate in nutrition sciences. Full professor and associate researcher, INHEM, Havana, Cuba.
María Elena Díaz-Sánchez, biologist with a master's degree in anthropology and doctorate in health sciences. Full professor and senior researcher, INHEM, Havana, Cuba.

Ana María Gómez-Álvarez, physician specializing in clinical biochemistry, with a master's degree in public health nutrition. Associate professor, Latin American School of Medicine, Havana, Cuba.

Derbis Campos-Hernández, biochemist with a master's degree in clinical biochemistry. Adjunct professor, INHEM, Havana, Cuba.

Caridad Arocha-Oriol, clinical laboratory technician, INHEM, Havana, Cuba.

Yoandry Díaz-Fuentes, nurse with a master's degree in emergency medicine. Instructor, INHEM, Havana, Cuba.

lleana Puentes-Márquez, nutritionist and dietitian, with a master's degree in public health nutrition, INHEM, Havana, Cuba.

Dania Herrera-Javier, biology technician, INHEM, Havana, Cuba.

Elisa Llera-Abreu, nutrition and dietetics technician, INHEM, Havana, Cuba.

Submitted: September 19, 2016

Approved for publication: June 29, 2017

Disclosures: None 